\title{
Evaluasi Pelaksanaan Program Pencegahan Stunting Ditinjau dari Intervensi Gizi Spesifik Gerakan 1000 HPK Di Puskesmas Pegang Baru Kabupaten Pasaman
}

\author{
Gina Muthia ${ }^{1}$, Edison², Eny Yantri ${ }^{3}$
}

\begin{abstract}
Abstrak
Periode kritis bagi pertumbuhan dan perkembangan anak yang disebut dengan 1000 Hari Pertama Kehidupan dipengaruhi oleh status gizi ibu pada saat pra-hamil, kehamilan dan saat menyusui. Masalah gizi yang dapat terjadi pada masa ini adalah stunting (pendek). Salah satu program yang terdapat dalam Gerakan 1000 Hari Pertama Kehidupan (HPK) dalam upaya mencegah stunting adalah intervensi gizi spesifik. Tujuan: Menganalisis evaluasi pelaksanaan program pencegahan stunting ditinjau dari intervensi gizi spesifik Gerakan 1000 HPK. Metode: Penelitian ini dilaksanakan di Puskesmas Pegang Baru menggunakan rancangan kualitatif dengan melakukan wawancara mendalam (Indepth Interview), observasi dan Focus Group Discussion (FGD). Komponen yang diteliti adalah input (pembiayaan, SDM, obat-obatan, pedoman dan SPO), process (perencanaan, pengorganisasian, penggerakkan, pengawasan, pencatatan dan pelaporan) dan output (pencapaian indikator gizi spesifik). Hasil: Komponen input; tidak ada dana khusus untuk intervensi gizi spesifik, masih kurangnya tenaga gizi dan belum ada pedoman dan SPO tentang penanganan growth faltering. Komponen proses; perencanaan belum dilakukan secara buttom up dan belum semua intervensi gizi spesifik mempunyai pencatatan pelaporan. Komponen output; balita yang mendapat kapsul vitamin A dan bumil Kurang Energi Kronis (KEK) yang mendapat PMT sudah memenuhi target capaian dan masih ada program intervensi gizi spesifik yang dillaksanakan tidak bisa dievaluasi. Simpulan: Pencegahan stunting melalui program intervensi gizi spesifik belum menurunkan stunting dibawah $20 \%$.
\end{abstract}

Kata kunci: evaluasi program, stunting, intervensi gizi spesifik

\begin{abstract}
The critical period of a child's growth and development is called the First 1000 Days of Life. It is influenced by the nutritional status of the mother during pre-pregnancy, pregnancy and breastfeeding time. Nutritional problems that can occur during this period is stunting (short). A program at the First 1000 Days of Life Movement (HPK) to prevent stunting is specific nutritional interventions. Objectives: To analyzed the evaluation of the implementation of the stunting prevention program was reviewed from the specific nutritional intervention of the 1000 HPK Movement. Methods: This research was conducted at the Pegang Baru Health Center. A qualitative research design by conducting in-depth interviews, observation and Focus Group Discussion (FGD). The components studied are inputs (funding, human resources, medicine, guidelines and SOP), process (planning, organizing, mobilizing, monitoring, recording and reporting) and output (achievement of specific nutritional indicators). Results: The input component; there are no special funds for specific nutritional interventions, there is still a lack of nutrition workers and there are no guidelines and SOP on handling growth faltering. Component process; planning has not been done button up and not all specific nutritional interventions have recorded and reported. The output component; toddlers who got vitamin $A$ capsules and pregnant women with chronic lack of energy who get supplementary feeding had fullfilled the target and some implementation of specific nutritional intervention programs still could not be evaluated. Conclusion: Preventing stunting through specific nutrition intervention program cannot reduce stunting below $20 \%$ yet.
\end{abstract}

Keywords: evaluation of program, stunting, specific nutrition interventions 
Affiliasi penulis: 1. Prodi DIII Kebidanan STIKes MERCUBAKTIJAYA Padang 2. Bagian IImu Kesehatan Masyarakat Fakultas Kedokteran Universitas Andalas Padang 3. Bagian IKA RSUP Dr. M. Djamil Padang

Korespondensi: Edison, Email : edisonaji@gmail.com

\section{PENDAHULUAN}

Stunting adalah tinggi badan dibawah standar deviasi WHO. Stunting pada anak menunjukkan rendahnya sosial ekonomi keluarga balita tersebut. ${ }^{1}$ Stunting tidak hanya mempengaruhi kognitif tapi juga akan mempengaruhi pertumbuhan dan pembangunan suatu negara karena akan mengakibatkan berkurangnya sumber daya manusia yang berkualitas. $^{2}$ Periode yang sangat kritis bagi pertumbuhan dan perkembangan anak dipengaruhi oleh status gizi ibu pada saat pra hamil, kehamilan dan saat menyusui. ${ }^{3}$ Gerakan 1000 Hari Pertama Kehidupan (1000 HPK) atau periode emas (golden periode) adalah periode yang dimulai sejak terjadinya konsepsi sampai anak berusia 2 tahun yang terdiri dari 270 hari selama kehamilan dan 730 hari kehidupan pertama sejak bayi dilahirkan. Salah satu program yang terdapat dalam Gerakan 1000 Hari Pertama Kehidupan (1000 HPK) dalam upaya mencegah stunting adalah intervensi gizi spesifik dengan sasaran ibu hamil, ibu menyusui dan anak usia 0-23 bulan. ${ }^{4}$

Riset Kesehatan Dasar (Riskesdas) 2013 mencatat prevalensi stunting di Indonesia mencapai $37,2 \%$, meningkat dari tahun 2010 sebesar $35,6 \%$ dan $36,8 \%$ pada tahun 2007. Prevalensi stunting di Indonesia lebih tinggi dari negara lain di Asia Tenggara seperti Myanmar (35\%), Vietnam (23\%), dan Thailand (16\%). ${ }^{5}$ Prevalensi stunting di Indonesia berdasarkan Riset Kesehatan Dasar (Riskesdas) tahun 2018 adalah 30,8\%. ${ }^{6}$ Persentase balita stunting (pendek) di Sumatera Barat tahun 2015-2017 adalah $19,4 \%, 18,9 \%$ dan $21,3 \%$ dari 19 Kabupaten/Kota yang ada Kabupaten Pasaman memiliki persentase tertinggi untuk stunting (pendek) yaitu 21,1\%, 25,7\% dan 25,1\%. ${ }^{7}$ Berdasarkan data status gizi balita Kabupaten Pasaman, dari 12 Kecamatan yang ada Kecamatan Panti dengan puskesmasnya adalah Puskesmas Pegang Baru dengan persentase balita stunting (pendek) tahun 2015-2017 adalah 17,3\%, $26 \%$ dan $16,8 \%{ }^{8}$
Intervensi gizi spesifik merupakan kegiatan yang ditujukan langsung pada kelompok sasaran tertentu yaitu balita, ibu hamil, remaja putri dan lainnya. ${ }^{9}$ The Lancet seri Ibu dan Anak menyatakan bahwa intervensi gizi spesifik telah terbukti dapat mengurangi stunting sebesar sepertiga dari prevalensi di dunia yaitu intervensi melalui suplementasi dan fortifikasi, mendukung pemberian ASI eksklusif, penyuluhan tentang pola makan anak, pengobatan untuk kekurangan gizi akut dan pengobatan infeksi. ${ }^{10}$

Survey awal yang dilakukan terhadap tujuh orang ibu balita stunting didapatkan bahwa enam orang ibu $(85,8 \%)$ mengalami KEK saat hamil dan mendapatkan Pemberian Makanan Tambahan (PMT) tetapi ibu jarang mengkonsumsinya, ibu memberikan ASI saja pada bayinya sampai usia bayinya 3 bulan dan ibu tidak selalu membawa bayinya ke posyandu dan bayinya tidak mendapatkan imunisasi dasar yang lengkap.

Berdasarkan informasi dari bidan yang bertugas di Puskesmas Pegang Baru mengatakan bahwa intervensi yang sudah dilakukan untuk mencegah stunting di Puskesmas Pegang Baru adalah PMT anak balita (pemberian biskuit), PMT ibu hamil KEK (pemberian susu dan biskuit), kegiatan antro setiap bulan di posyandu dan pemberian vitamin A dan garam beryodium. Berdasarkan latar belakang tersebut peneliti tertarik melakukan penelitian tentang Analisis Pelaksanaan Program Pencegahan Stunting ditinjau dari Intervensi Gizi Spesifik Gerakan 1000 HPK.

Tujuan penelitian ini adalah menganalisis bagaimana evaluasi pelaksanaan program pencegahan stunting ditinjau dari Intervensi Gizi Spesifik Gerakan 1000 HPK.

\section{METODE}

Penelitian ini menggunakan rancangan studi kualitatif yang bertujuan untuk mendapatkan gambaran mendalam tentang evaluasi pelaksanaan program pencegahan stunting ditinjau dari intervensi gizi spesifik Gerakan 1000 HPK di Puskesmas Pegang Baru Kabupaten Pasaman. Penelitian ini telah dilakukan dari September 2018 sampai Juni 2019. 
Pemilihan informan dalam penelitian ini menggunakan teknik purposive sampling. Informan dalam penelitian ini adalah Kepala Dinas Kesehatan Kabupaten Pasaman, Kasie Gizi dan Kesga, Kepala Puskesmas Pegang Baru, Pemegang Program Gizi, Pemegang Program KIA lbu dan Anak, Pemegang Program Imunisasi, Pemegang Program Promkes dan ibu dengan balita stunting.

Komponen yang diteliti adalah Input (pembiayaan, SDM, obat-obatan, pedoman dan $\mathrm{SPO}$ ), Process (perencanaan, pengorganisasian, penggerakkan, pengawasan, pencatatan dan pelaporan) dan Output (pencapaian indikator gizi spesifik).

Data primer diperoleh dengan cara wawancara mendalam (indepth interview) dan Focus Group Discussion (FGD) kepada informan penelitian yang meliputi informasi tentang komponen input, process dan output yang berhubungan dengan evaluasi pelaksanaan program intervensi gizi spesifik di Puskesmas Pegang Baru. Data sekunder diperoleh dari observasi melalui telaah dokumen yang meliputi laporan capaian intervensi gizi spesifik.

\section{HASIL}

\section{Komponen Input}

- Pembiayaan

Hasil wawancara mendalam dan observasi dengan telaah dokumen didapatkan bahwa pembiayaan khusus untuk kegiatan intervensi gizi spesifik tidak ada. Kegiatan-kegiatan dalam program intervensi gizi spesifik merupakan kegiatan yang biasa dilakukan di puskesmas yang menggunakan dana JKN karena pencairan dana BOK yang terlambat

\section{- Sumber Daya Manusia}

Hasil wawancara mendalam, observasi dengan telaah dokumen dan FGD didapatkan bahwa jumlah sumber daya manusia untuk kegiatan intervensi gizi spesifik masih kurang untuk tenaga gizi, tenaga gizi yang ada saat ini berjumlah satu orang dengan tingkat pendidikan Diploma III (DIII). Pelatihan yang telah diikuti adalah pelatihan pemberian makanan pada bayi dan anak, surveilans gizi dan konseling ibu menyusui.
- Obat-obatan

Hasil wawancara mendalam dan observasi dengan telaah dokumen didapatkan bahwa ketersediaan obat-obatan untuk pelaksanaan intervensi gizi spesifik sudah cukup dan distribusi lancer, tetapi kadang-kadang ada obat-obatan yang didistribusikan ke dinas sudah mendekati batas kadaluarsa, misalnya vitamin A. Obat-obatan ini didistribusikan dari Dinas Kesehatan Provinsi ke Dinas Kesehaatn Kabupaten/Kota kemudian didistribusikan ke puskesmas.

\section{- Pedoman dan SPO}

Hasil wawancara mendalam dan observasi dengan telaah dokumen didapatkan bahwa Dinas Kesehatan sudah memberikan panduan/pedoman kepada puskesmas untuk melaksanakan intervensi gizi spesifik tetapi belum dilaksanakan dan ditempel di dinding ruangan. Panduan/pedoman dan SPO belum digunakan secara efektif karena masih sebagai kelengkapan administrasi dan juga masih ada kegiatan yang belum mempunyai pedoman dan SPO yaitu penanganan growth faltering.

\section{Komponen Process}

\section{- Perencanaan}

Hasil wawancara mendalam dan observasi telaah dokumen didapatkan bahwa perencanaan yang berkaitan dengan intervensi gizi spesifik dilakukan dari bawah keatas (bottom up) sesuai dengan permasalahan yang ada di puskesmas. Pihak puskesmas mengatakan bahwa perencanaan yang dilakukan terkait dengan kegiatan intervensi gizi spesifik masih dengan sama dengan tahun sebelumnya yang berarti puskesmas belum membuat perencanaan yang kemudian diajukan ke dinas kesehatan seperti yang diharapkan oleh dinas kesehatan.

\section{- Pengorganisasian}

Hasil wawancara mendalam dan observasi dtelaah dokumen didapatkan bahwa pengorganisasian program intervensi gizi spesifik melibatkan lintas program, lintas sektoral dan UPT lain dan sudah ada SK Kepala Dinas dan edaran bupati untuk membentuk tim penanggulangan stunting. 


\section{- Penggerakkan}

Hasil wawancara mendalam dan observasi dengan telaah dokumen didapatkan bahwa penggerakan program intervensi gizi spesifik dilakukan secara berjenjang dari kabupaten, kecamatan, nagari dan masyarakat tapi belum semua tokoh masyarakat terlibat dan belum didukung dokumen yang lengkap.

\section{- Pengawasan}

Hasil wawancara mendalam dan observasi dengan telaah dokumen didapatkan bahwa pengawasan dilakukan satu kali sebulan secara berjenjang dari propinsi ke kabupaten oleh bidang kesehatan masyarakat melalui seksi gizi dan kesga berupa kegiatan monitoring dan evaluasi.

\section{- Pencatatan dan pelaporan}

Hasil wawancara mendalam dan observasi dengan telaah dokumen didapatkan bahwa pencatatatan dan pelaporan untuk program intervensi gizi spesifik dilakukan setiap bulan dari puskesmas kemudian dilaporkan ke dinas kesehatan. Data yang dicatat dan dilaporkan tersebut didapatkan oleh pemegang program dari bidan desa yang diterima setiap tanggal 25 setiap bulannya tetapi belum semua program intervensi gizi spesifik yang mempunyai pencatatan pelaporan.

\section{Komponen Output}

Hasil wawancara mendalam didapatkan bahwa masih ada pencapaian indikator gizi spesifik yang belum mencapai target bahkan ada yang tidak tercapai $(0 \%)$ yaitu rumah tangga yang mengkonsumsi garam beryodium. Kegiatan lain dari program intervensi gizi spesifik yang sudah dilakukan di Puskesmas Pegang Baru adalah obat cacing, zinc untuk pencegahan dan pengobatan diare (laporannya tidak ada) dan edukasi tentang MP-ASI melalui pelaksanaan kelas ibu balita. Program intervensi gizi spesifik yang belum dilakukan di Puskesmas Pegang Baru adalah fortifikasi zat besi dalam makanan karena belum tersedianya pabrik lokal untuk menyediakan produk makanan tersebut dan perlindungan terhadap malaria karena daerah tersebut bukan daerah endemik malaria.

\section{PEMBAHASAN}

\section{Komponen Input}

- Pembiayaan

Hasil pengumpulan data didapatkan pembiayaan untuk program kesehatan termasuk intervensi gizi spesifik dari Dinas Kesehatan ke Puskesmas menggunakan dana BOK yang direalisasikan dari pusat pada bulan keempat setiap tahun dan belum ada anggaran atau pembiayaan khusus untuk program intervensi gizi spesifik.

Penelitian ini sama dengan yang dilakukan oleh Syafrina et al (2018) yang berjudul Analisis Komitmen Pemerintah Kabupaten Padang Pariaman dalam Mengatasi Masalah Stunting Berdasarkan Nutrition Commitment Index 2018 yang menyatakan bahwa Dinas Kesehatan Kabupaten Padang Pariaman belum memiliki anggaran dana khusus untuk pencegahan stunting sehingga diperlukan adanya advokasi kepada pemerintah daerah dan DPRD untuk mendapatkan dukungan dana pencegahan stunting di Kabupaten Padang Pariaman. ${ }^{11}$

Hasil penelitian Lubis et al (2008) yang berjudul Analisis Implementasi Program Penanggulangan Gizi Buruk Pada Anak Balita di Wilayah Kerja Puskesmas Medan Labuhan, Kota Medan tahun 2008 menyatakan bahwa dana penanggulangan gizi buruk langsung dikelola oleh Dinas Kesehatan Kota (DKK) yang bersumber dari Anggaran Pendapatan dan Belanja Daerah (APBD) dan Puskesmas hanya mendistribusikan atau sebagai pelaksana. ${ }^{12}$

Berdasarkan Permenkes tentang Pusat Kesehatan Masyarakat dijelaskan bahwa pembiayaan kegiatan di puskesmas bersumber dari Anggaran Pendapatan Belanja Daerah (APBD), Anggaran Pendapatan Belanja Negara (APBN) dan sumbersumber lain yang sah dan tidak mengikat. ${ }^{13}$

Menurut peneliti, ketersediaan dana untuk kegiatan yang ada dalam program intervensi gizi spesifik sudah mencukupi karena jumlah dana BOK yang disediakan oleh pemerintah cukup besar. Ketersedian dana khusus dari pemerintah untuk program intervensi gizi spesifik juga diperlukan agar kegiatan yang dilaksanakan dapat ditingkatkan lagi dari segi kualitas misalnya adanya kegiatan kunjungan rumah untuk pemantauan ibu mulai pra konsepsi 
sampai bayi berusia 2 tahun, pengadaan media promosi yang lebih inovatif.

\section{- Sumber Daya Manusia}

Berdasarkan hasil wawancara dengan informan diketahui bahwa sumber daya manusia untuk program intervensi gizi spesifik di Puskesmas Pegang Baru masih kurang untuk tenaga gizi, tenaga gizi yang ada saat ini berjumlah satu orang dengan tingkat pendidikan adalah Diploma III (DIII). Kegiatan-kegiatan dalam intervensi gizi spesifik memerlukan koordinasi dengan lintas program seperti KIA ibu, KIA anak, gizi, promkes, imunisasi dan kesling.

Hasil ini sama dengan penelitian yang dilakukan oleh Khoeroh dan Indriyanti (2017) yang berjudul Evaluasi Penatalaksanaan Gizi Balita Stunting di Wilayah Kerja Puskesmas Sirampog yang menyatakan bahwa dari segi SDM masih memerlukan tambahan untuk posisi koordinator gizi. Tugas dalam penatalaksanaan balita stunting sudah terintegrasi namun belum ada team khusus serta tupoksi belum sesuai dengan kompetensi, terutama koordinator gizi dipegang oleh bidan. ${ }^{14}$

Hasil FGD informan menyatakan bahwa dari 7 orang ibu balita stunting, 5 orang ibu balita stunting jarang membawa balitanya ke posyandu sehingga ibu tidak mengetahui pertumbuhan balitanya saat usia 4-6 bulan dimana usia tersebut merupakan usia kritis untuk mengalami gagal tumbuh (growth faltering). Sedangkan 2 orang ibu balita yang datang ke posyandu, balitanya mengalami penurunan BB saat usia 4 bulan dan tenaga kesehatan menyampaikan kepada ibu untuk tetap memberikan ASI kepada bayinya. Hasil penelitian yang dilakukan oleh Destiadi et al (2015) yang berjudul Frekuensi Kunjungan Posyandu dan Riwayat Kenaikan Berat Badan sebagai Faktor Risiko Kejadian Stunting Pada Anak Usia 3-5 tahun menyatakan bahwa frekuensi kunjungan posyandu dan kenaikan berat badan merupakan faktor risiko terhadap kejadian stunting. ${ }^{15}$

Menurut peneliti, walaupun kegiatan dalam program intervensi gizi spesifik melibatkan lintas program seperti KIA ibu, KIA anak, promkes, imunisasi, kesling, bidan desa dan kader tetapi diperlukan adanya penambahan tenaga gizi untuk lebih memaksimalkan kegiatan dalam program intervensi gizi spesifik yang kegiatannya lebih mengarah kepada perbaikan gizi ibu mulai dari hamil sampai bayinya berusia 2 tahun. Tenaga kesehatan juga berperan dalam kegiatan posyandu untuk memantau pertumbuhan dan perkembangan balita sehingga apabila saat bayi berusia 4-6 bulan mengalami gagal tumbuh (growth faltering) dapat segera ditindaklanjuti.

\section{- Obat-obatan}

Berdasarkan hasil wawancara yang dilakukan kepada informan tentang obat-obatan untuk penyelenggaraan intervensi gizi spesifik didapatkan bahwa ketersediaannya sudah cukup dan subsidi dari dinas kesehatan propinsi. Obat-obatan didistribusikan dari dinas kesehatan kabupaten ke puskesmaspuskesmas sesuai dengan sasaran.

Hasil penelitian ini sama dengan penelitian yang dilakukan oleh Khoeroh dan Indriyanti (2017) yang berjudul Evaluasi Penatalaksanaan Gizi Balita Stunting di Wilayah Kerja Puskesmas Sirampog yang menyatakan bahwa ketersediaan obat-obatan sudah cukup mendukung dalam penatalaksanaan balita stunting, diantaranya; obat-obatan, vitamin, mikronutrient serta peralatan yang digunakan untuk pemeriksaan yang pembiayaannya disubsidi dari Dinas Kesehatan Kabupaten. ${ }^{14}$

Menurut peneliti ketersediaan obat-obatan di Puskesmas Pegang Baru sudah cukup dan distibusinya lancar tetapi terkendala untuk vitamin $A$ yang pendistribusiannya ke puskesmas dari dinas kesehatan propinsi melalui dinas kesehatan kabupaten sudah mendekati batas kadaluarsa. Hal ini juga disampaikan oleh informan bahwa pendistribusian obat-obatan lancar tapi terkendala untuk vitamin A yang didistribusikan dari pusat ke dinas sudah mendekati expired.

\section{- Pedoman dan SPO}

Hasil pengumpulan data melalui wawancara mendalam dengan informan didapatkan bahwa untuk pedoman dan SPO kegiatan intervensi spesifik sudah ada di Puskesmas Pegang Baru apalagi Puskesmas Pegang Baru sudah terakreditasi tingkat madya. Dinas 
kesehatan sudah memberikan panduan dalam menjalankan program gizi umumnya dan intervensi gizi spesifik khususnya.

Hasil observasi yang peneliti lakukan di bagian KIA Ibu, KIA anak, imunisasi, gizi dan promkes, di setiap ruangan sudah ada SPO yang ditempel di dinding dan dalam melakukan tindakan atau pemeriksaan ada yang sudah sesuai SPO dan ada yang belum sesuai dengan SPO, karena masih ada SPO yang diletakkan dalam lemari.

Menurut peneliti perlunya pengawasan dari pimpinan puskesmas dalam penggunaan pedoman dan SPO untuk semua kegiatan yang dilakukan di puskesmas dan kegiatan dari program intervensi gizi spesifik sehingga pedoman dan SPO tidak hanya sebagai kelengkapan administrasi saja. Selain itu masih ada kegiatan yang belum mempunyai pedoman dan SPO yaitu penanganan growth faltering.

\section{Komponen Process}

- Perencanaan

Hasil pengumpulan data bahwa perencanaan program dibuat dari bawah ke atas (buttom up) yaitu puskesmas membuat rencana berdasarkan evaluasi program tahun sebelumnya kemudian rencana tersebut disampaikan kepada dinas kesehatan belum dilakukan oleh puskesmas seperti hal tersebut diatas sehingga kegiatan dalam upaya pencegahan stunting masih sama dengan kegiatan yang rutin dilakukan. Perencanaan program intervensi gizi spesifik juga melibatkan lintas program lain misalnya promkes, kesling, P2P dan lintas sektoral.

Berbeda dengan penelitian yang dilakukan oleh Syafrina et al (2018) yang berjudul Analisis Komitmen Pemerintah Kabupaten Padang Pariaman dalam Mengatasi Masalah Stunting Berdasarkan Nutrition Commitment Index 2018 yang menyatakan bahwa perencanaan program gizi di Dinas Kesehatan Kabupaten Padang Pariaman dibuat setiap tahun dalam bentuk rencana kerja dengan mengidentifikasi permasalahan dari evaluasi pencapaian sebelumnya. ${ }^{11}$

Menurut peneliti walaupun kegiatan yang dilaksanakan sama dengan kegiatan rutin yang biasa dilakukan puskesmas tetapi dapat ditingkatkan dari segi kualitasnya misalnya konseling kepada wanita pra nikah, kunjungan rumah untuk memantau ibu hamil sampai bayi berusia dua tahun dan kegiatan-kegiatan memang membutuhkan dana yang lebih dari dana sudah dialokasikan sehingga perlu adanya dana khusus untuk kegiatan-kegiatan dalam program intervensi gizi spesifik. Program intervensi gizi spesifik berdasarkan Kementrian Kesehatan adalah PMT pada ibu hamil KEK, TTD dan asam folat pada ibu hamil anemia, yodium, obat cacing pada ibu hamil, obat malaria pada ibu hamil, IMD, ASI eksklusif, ASI 2 tahun-MP ASI, imunisasi, suplementasi zinc, obat cacing, fortifikasi zat besi dalam makanan, perlindungan terhadap malaria, pencegahan dan pengobatan diare.

\section{- Pengorganisasian}

Hasil wawancara mendalam yang dilakukan kepada informan didapatkan bahwa pengorganisasian di tingkat kabupaten sudah ada Kelompok kerja (Pokja) penanggulangan stunting dan melibatkan UPT terkait misalnya dinas pangan, pengendalian penduduk dan keluarga berencana, perikanan, BAPPEDA, RS dan dinas lain sehingga intervensi gizi spesifik didukung oleh intervensi gizi sensitif.

Hasil penelitian ini sama dengan yang dilakukan oleh Rosa et al (2016) yang berjudul Peran Intervensi Gizi Spesifik dan Sensitif dalam Perbaikan Masalah Gizi Balita di Kota Bogor yang menyatakan bahwa upaya penanggulangan masalah gizi di Kota Bogor juga dilakukan oleh lembaga lain misalnya lurah, dinas pangan, PKK, dinas kependudukan, perikanan dan Bappeda. ${ }^{9}$

Menurut peneliti dalam melaksanakan kegiatan program intervensi gizi spesifik memerlukan koordinasi dengan lintas program dan lintas sektoral karena selain dalam bidang kesehatan, upaya pencegahan stunting juga dilakukan dengan melibatkan bidang non kesehatan seperti dinas pangan, kependudukan dan keluarga berencana. Puskesmas Pegang Baru dalam menyelenggarakan program intervensi gizi spesifik sudah melibatkan beberapa lintas program seperti gizi, KIA ibu, KIA anak, Promkes, Kesling dan lintas sektoral seperti kecamatan, nagari, kader kesehatan, dinas pendidikan, dinas sosial, PKK, BAZNAS dan KUA. 


\section{- Penggerakkan}

Hasil wawancara mendalam kepada informan didapatkan bahwa penggerakan di tingkat kabupaten dilakukan dengan melaksanakan rapat koordinasi dengan Pokja stunting dan Kepala Bidang (Kabid). Pihak Kabupaten melalui surat edaran bupati dan dinas kesehatan menyampaikan kepada pihak kecamatan dan nagari untuk menggerakkan tokoh masyarakat, masyarakat dan melibatkan mereka dalam kegiatan yang berkaitan dengan intervensi stunting.

Menurut peneliti, pencegahan stunting dapat dilakukan dengan memberdayakan masyarakat untuk mendukung kegiatan yang ada dalam program intervensi gizi spesifik. Hal tersebut sudah dilakukan oleh Puskesmas Pegang Baru dengan melibatkan masyarakat dalam kegiatan intervensi gizi spesifik dalam upaya pencegahan stunting seperti kecamatan, nagari, PKK walaupun belum semua tokoh masyarakat yang terlibat. Contoh kegiatannya adalah demonstrasi dan penyuluhan tentang MP-ASI yang dilakukan oleh PKK dan bagian gizi di Puskesmas Pegang Baru.

Menurut Husaini (2000) dalam Rahmayana et al (2014) menyatakan bahwa peran keluarga terutama ibu dalam mengasuh anak akan menentukan tumbuh kembang anak tersebut. Peran ibu dalam mengasuh anaknya dipengaruhi oleh pendidikan formal ibu, dimana semakin tinggi tingkat pendidikan formal ibu, semakin tinggi juga pengetahuan ibu dalam menyerap informasi tentang pola asuh terhadap anaknya seperti pengetahuan tentang ASI eksklusif, waktu pemberian MP-ASI dan jenis MP-ASI yang diberikan kepada anaknya sesuai dengan tahapan umurnya. ${ }^{16}$

Hasil FGD informan didapatkan bahwa dari 7 orang ibu balita stunting, 5 orang ibu balita stunting sudah memberikan makanan selain ASI kepada bayinya misalnya sudah memberikan bubur saat bayinya berusia 3 bulan, sudah memberikan susu SGM saat bayinya berusia 2 hari dan memberikan biskuit pada bayinya saat bayinya berusia 5 bulan. Ibu balita juga mengatakan bahwa mereka mengikuti kegiatan yang dilakukan oleh PKK tentang demonstrasi dan penyuluhan MP-ASI saat ibu-ibu tersebut masih hamil tetapi ibu tidak menerapkannya karena anak yang sebelumnya, ibu juga menerapkan pola makan yang sama seperti kepada anak yang sekarang yaitu makan 3xsehari (2 kali makan makanan pokok dan mengkonsumsi jajanan (tidak selalu terdapat protein dalam makanannya).

Hal tersebut juga disampaikan oleh salah satu informan yang menyatakan bahwa ibu-ibu saat hamil sudah dibekali tentang MP-ASI yang disampaikan melalui kegiatan PKK dan penyuluhan di posyandu tapi mereka kurang paham tentang frekuensi makanan yaitu mereka tetap memberikan makanan 3 kali sehari tetapi makan makanan pokok hanya dua kali sehari, tidak selalu mengkonsumsi protein dan mengkonsumsi jajanan.

Penelitian yang dilakukan oleh Aridiyah et al (2015) yang berjudul Faktor-Faktor yang Mempengaruhi Kejadian Stunting pada Anak Balita di Wilayah Pedesaan dan Perkotaan menyatakan bahwa terdapat hubungan antara pengetahuan ibu tentang gizi, pemberian ASI eksklusif dan umur pemberian MP-ASI pertama kali dengan kejadian stunting di Puskesmas Patrang, Puskesmas Mangli dan Puskesmas Kalisat Kabupaten Jember. ${ }^{17}$

Penelitian dengan hasil yang sama juga dilakukan oleh Najahah et al (2013) yang berjudul Faktor Risiko Balita Stunting Usia 12-36 Bulan di Puskesmas Dasan Agung, Mataram, Provinsi Nusa Tenggara Barat menyatakan bahwa pemberian MPASI dini merupakan faktor risiko balita stunting dengan nilai $\mathrm{OR}=6,38 .{ }^{18}$

\section{- Pengawasan}

Berdasarkan hasil wawancara mendalam kepada informan didapatkan bahwa pengawasan untuk intervensi gizi spesifik dilakukan berjenjang mulai dari pusat ke propinsi, propinsi ke kabupaten, kabupaten ke puskesmas atau langsung dari kabupaten ke nagari yang dilakukan secara rutin. Pengawasan dilakukan satu kali sebulan oleh dinas kesehatan melalui bidang kesehatan masyarakat melalui Seksi gizi dan Kesehatan keluarga (Kesga).

Menurut peneliti, pengawasan untuk kegiatan intervensi gizi spesifik melibatkan seluruh pemegang program di puskesmas dan lintas sektoral dengan melakukan monev per bulan sehingga kegiatan yang 
belum dilaksanakan atau mengalami kendala dapat diketahui sejak awal dan segera dilakukan upaya untuk mengatasinya.

\section{- Pencatatan dan pelaporan}

Wawancara mendalam kepada informan didapatkan bahwa pencatatan dan pelaporan kegiatan intervensi gizi spesifik dilakukan oleh masing-masing program setiap bulan, setiap selesai kegiatan dan segera apabila ada kasus. Indikator gizi spesifik adalah salah satu kegiatan dari gerakan 1000 HPK dengan sasaran ibu hamil, ibu menyusui dan anak usia 0-23 bulan. Untuk kegiatan tersebut tidak semuanya sudah ada laporan di puskesmas, laporan yang sudah ada adalah imunisasi dasar, IMD, ASI eksklusif, pemberian tablet Fe, KIE pemberian MP-ASI dalam kegiatan kelas ibu balita, vitamin $A$, penanganan gizi buruk akut melalui pemberian PMT, dan PMT pada ibu hamil KEK.

Menurut peneliti semua kegiatan yang terdapat dalam program intervensi gizi spesifik sebaiknya dilakukan pencatatan dan pelaporannya. Apabila kegiatan belum mencapai target maka dilakukan upaya untuk mencari permasalahannya dan menentukan upaya untuk mengatasi permasalahan tersebut. Hasil dari permasalahan yang didapatkan dan pemecahan masalahnya menjadi perencanaan di periode berikutnya yang disampaikan oleh pihak puskesmas ke dinas kesehatan sehingga sesuai dengan yang disampaikan oleh Sekretaris Dinas Kesehatan bahwa perencanaan program dibuat dari bawah ke atas (buttom up).

\section{Komponen Output}

Berdasarkan hasil penelitian di dapatkan bahwa capaian program intervensi gizi spesifik masih ada yang belum mencapai target contohnya adalah cakupan imunisasi dasar. Hal ini terjadi karena masih ada suami ibu yang mempunyai bayi yang tidak mengizinkan anaknya untuk diimunisasi. Hasil FGD informan menyatakan bahwa ada balita yang tidak mendapatkan imunisasi dasar lengkap karena suami tidak mengizinkan balitanya untuk diimunisasi. Selain itu juga ada balita yang hanya mendapatkan imunisasi Hb0, BCG dan DPT 1 saja dan tidak mendapatkan lagi imunisasi yang lain karena setelah mendapatkan imunisasi, balita menjadi demam sehingga suami ibu tidak mengizinkan lagi balitanya untuk diimunisasi.

Hasil penelitian juga didapatkan bahwa capaian program intervensi gizi spesifik yaitu ASI eksklusif belum mencapai target. Informan FGD menyatakan bahwa mereka memberikan ASI saja pada bayinya sampai usia 3 bulan pertama, kemudian 3 bulan berikutnya mereka memberikan bubur yang dibuat dari beras yang ditumbuk kemudian dicampur dengan gula aren. Informan lain juga menyatakan bahwa saat bayinya berumur 2 hari mereka memberikan susu formula karena ASI yang tidak keluar, kemudian mereka memberikan ASI lagi sampai usia 4 bulan dan setelah usia 4 bulan mereka memberikan bubur susu.

\section{SIMPULAN}

Pencegahan stunting melalui program intervensi gizi spesifik cukup baik.

\section{UCAPAN TERIMA KASIH}

Terima kasih kepada semua pihak yang telah memberikan kontribusi dalam pelaksanaan penelitian ini.

\section{DAFTAR PUSTAKA}

1. World Health Organization (WHO). What's at stake. 2014. Tersedia dari: https://doi.org/10.1111/evo.12990

2. Marini A, Rokx C, Gallagher P. Standing tall: Peru's success in overcoming its stunting crisis. World Bank Group; 2017.

3. Zaif RM, Wijaya M, Hilmanto D. Hubungan antara riwayat status gizi ibu masa kehamilan dengan pertumbuhan anak balita di kecamatan Soreang Kabupaten Bandung. Jurnal Sistem Kesehatan. 2016; 2(3):156-63

4. Bappenas RI. Pedoman perencanaan program gerakan sadar gizi dalam rangka seribu hari pertama kehidupan (1000 HPK). Jakarta: Bappenas RI; 2012.

5. Badan Penelitian dan Pengembangan Kesehatan. Hasil Utama Riskesdas. Jakarta: Kementerian Kesehatan RI (Kemenkes RI); 2013.

6. Badan Penelitian dan Pengembangan. Hasil utama riskesdas. Jakarta: Kemenkes RI; 2018. 
7. Dinas Kesehatan Provinsi Sumbar. Laporan status gizi balita dan data indikator gizi kab/kota. Padang: Dinas Kesehatan Provinsi Sumbar; 2018.

8. Dinas Kesehatan Kabupaten Pasaman. Laporan status gizi balita dan data indikator gizi. Pasaman: Dinas Kesehatan Kabupaten Pasaman; 2018.

9. Rosa BCh, Sari K, Yunita SP, Amaliah N, Utami $\mathrm{NH}$. Peran intervensi gizi spesifik dan sensitif dalam perbaikan masalah gizi balita di kota Bogor. Buletin Penelitian Kesehatan. 2016;44(2):127-38.

10. The Lancet. Executive summary of the lancet maternal and child nutrition series. The Lancet. 2013.

11. Syafrina M, Masrul, Firdawati. Analisis komitmen pemerintah kabupaten padang pariaman dalam mengatasi masalah stunting berdasarkan nutrition commitment index. Jurnal Kesehatan Andalas.2018;7(2):233-44.

12. Lubis Z, Tampubolon E, Jumirah. Analisis implementasi program penanggulangan gizi buruk pada anak balita di wilayah kerja puskesmas Medan Labuhan Kota Medan tahun 2008. Penel Gizi Makanan. 2012;35(1):70-7.

13. Peraturan Menteri Kesehatan Republik Indonesia No 44 Tahun 2016 Tentang Pedoman Manajemen
Puskesmas. Jakarta: Kementrian Kesehatan RI; 2016

14. Khoeroh $\mathrm{H}$, Indriyanti D. Evaluasi penatalaksanaan gizi balita stunting di wilayah kerja puskesmas Sirampog. Unnes Journal of Public Health. 2017;6 (3):189-95.

15. Destiadi A, Nindya TS, Sumarmi S. Frekuensi kunjungan posyandu dan riwayat kenaikan berat badan sebagai faktor risiko kejadian stunting pada anak usia 3-5 tahun. Media Gizi Indonesia. 2015; 10(1):71-75

16. Rahmayana, Ibrahim IA, Damayanti DS. Hubungan pola asuh ibu dan kejadian stunting anak usia 2459 bulan di Posyandu Asoka II wilayah pesisir kelurahan Barombong Kecamatan Tamalate Kota Makassar. Publich Health Science Journal. 2014; $\mathrm{VI}(2): 424-36$.

17. Aridiyah FO, Rohmawati N, Ririanty M. Faktorfaktor yang mempengaruhi kejadian stunting pada anak balita di wilayah pedesaan dan perkotaan. eJurnal Pustaka Kesehatan. 2015;3(1):163-70.

18. Najahah I, Adhi KT, Pinatih GNI. Faktor risiko balita stunting usia 12-36 bulan di puskesmas Dasan Agung Mataram Provinsi Nusa Tenggara Barat. OJS Unud. 2013;1(2):134-41. 